\title{
Eleştirel Liderlik Stili Ölçeği: Geçerlik ve Güvenirlik Çalışması ${ }^{1}$
}

\author{
DOI: 10.26466/opus.552489
}

\author{
$\underline{\text { Cenk Aygün}}^{*}$-Mustafa Özgenel ${ }^{* *}$ \\ * Dr., İstanbul Sabahattin Zaim Üniversitesi, Eğitim Fakültesi, İstanbul/Türkiye \\ E-Posta: cenkaygun92@gmail.com \\ ORCID: $\quad \underline{0000-0002-0534-9880}$ \\ ** İngilizce Öğretmeni, Milli Eğitim Bakanlığı, İstanbul/Türkiye \\ E-Posta: mustafa.ozgenel@izu.edu.tr ORCID: $\quad \underline{0000-0002-7276-4865}$
}

Öz

Araştırmanın amacl, eğitim yönetimi alanında ihtiyaç duyulan eleştirel liderlik stilini geçerli ve güvenilir bir şekilde ölçen Likert türü bir ölçek geliştirmektir. Eleştirel Liderlik Stili Ölçeği Jenkins ve Cutchens'ın (2011) "Leading Critically" isimli gömülü teori çalışmasında yer alan 12 eleştirel liderlik eylemi temel alınarak geliştirilmiştir. Öncelikle literatür taraması sonucunda 41 maddelik madde havuzu ve taslak ölçek formu oluşturulmuştur. 41 maddelik taslak ölçek formu uzmanların ve öğretmenlerin görüşleri doğrultusunda 36'ya düşürülmüştür. Ölçek formu 5'li likert olarak derecelendirilmiştir. Açımlayıcı faktör analizi için 359, doğrulayıcı faktör analizi için 349 ve test tekrar test analizi için 38 öğretmenden veri toplanmıştır. Açımlayıcı faktör analizinden elde edilen faktör yapısı doğrulayıcı faktör analizi ile doğrulanmiştır. Yapılan faktör analizi sonucunda 4 alt boyut ve 30 maddeden oluşan yap doğrulayıcı faktör analiz ile test edilmiştir. Güvenirlik düzeyini belirlemek amactyla elde edilen veriler üzerinden hesaplanan Cronbach Alpha iç-tutarlılık katsayısı 0.969 olarak belirlenmiştir. Analizler sonucunda ölçeğin geçerli ve güvenilir bir ölçme aracı olduğu belirlenmiştir.

Anahtar Kelimeler: Eleştirel düşünme, liderlik, eleştirel liderlik

\footnotetext{
${ }^{1}$ Bu çalışma, Cenk Aygün'ün Dr. Mustafa Özgenel danışmanlığında yürütülen yüksek lisans tezinden üretilmiştir.
} 


\title{
Critical Leadership Style Scale: Validity and Reliability Study
}

\begin{abstract}
The aim of the study is to develop a Likert type scale which measures the critical leadership style needed in the field of education management in a valid and reliable manner. The Critical Leadership Style Scale was developed based on the 12 critical leadership actions included in Jenkins and Cutchens's (2011) grounded theory study which is called "Leading Critically". First of all, a pool of 41 items and a draft scale form were created as a result of literature review. The 41-item draft scale form was reduced to 36 according to the opinions of experts and teachers. The form of the scale was created as 5-point Likert scale. The data were collected from 349 teachers for the confirmatory factor analysis, from 359 teachers for the confirmatory factor analysis and from 38 teachers for test-retest analysis. The factor structure obtained from the exploratory factor analysis was confirmed by confirmatory factor analysis. As a result of factor analysis, the structure consisting of 4 sub-dimensions and 30 items was tested with confirmatory factor analysis. The Cronbach Alpha internal consistency coefficient was calculated as 0.969 based on the data obtained to determine the reliability level of the scale. As a result of the analyzes, it was determined that the scale was a valid and reliable measurement instrument.
\end{abstract}

Keywords: Critiacal thinking, leadership, critical leadership.. 


\section{Giriş}

Günümüz dünyasında çeşitli alanlarda yaşanan değişimler ve ortaya çıkan yeni problemler liderliğin önemi oldukça artırmıştır. Katz ve Kahn'a (1977) göre liderlik “bir durumdan kazanılan sıfat, bir kişinin özelliği ve davranışı" olarak üç temel anlamda tanımlanmaktadır. Bennis (1990, s.18) başarılı liderlerin çalışanlarına kendilerini önemli hissettirerek iham vermeleri gerektiğini, ayrıca bu liderlerin çalışanlarını ailenin bir parçası gibi hissettirmelerinin önemli olduğunu vurgular. Lider ve yönetici arasındaki en önemli farkı ise şöyle aktarır: "Liderler doğru işleri yaparlar, yöneticiler ise işleri doğru yaparlar." Liderlik ortak bir hedef doğrultusunda takipçileri motive etme ve onlara yol gösterebilme yeteneğidir denilebilir.

Eğitim örgütlerinde belirlenen hedefler doğrultusunda öğretmen, öğrenci ve tüm paydaşların yönlendirilmeye ve motive edilmeye ihtiyacı vardır. Günümüzde eğitim liderliği çalışmalarının giderek liderin bilişsel özelliklerine odaklandığını söylemek mümkündür. Bu nedenden dolayı liderin düşünme becerileri önem kazanmıştır. Presseisen (1985, s.35-37) düşünme becerilerini; temel işlemler, problem çözme, karar verme, eleştirel düşünme ve yaratıcı düşünme olarak sınıflandırmıştır. Bu düşünme becerilerden bir olan eleştirel düşünme, düşünme becerileri arasında en karmaşık olanlarından biri olarak kabul edilebilir. Eleştirel düşünme becerisindeki eleştirel kelimesi, Latince "criticus" kelimesinden gelmektedir. İngilizceye "critical" olarak geçmiştir. Liderlik kavramıyla ilgili yapılan araştırmalarda liderin sahip olması gereken becerilerin arasında eleştirel düşünme becerilerinin yer aldığı ortaya çıkmıştır.

Ennis (1985, s.45-46) eleştirel düşünmenin yargılama, bilginin geliştirilmesi ve sorgulama olmak üzere 3 yapısı olduğundan bahsetmiştir. Eleştirel düşünme beceri ve eğilimlerinden bazılarını ise şu şekilde sıralamıştır: Sorunu açıkça belirleme, nedenleri arama, iyi bilgilendirilme, güvenilir kaynakları kullanma, temel noktaya bağlı kalabilme, açık fikirli olma, başkalarının görüşlerini dikkate alma, diğerlerinin duygularına ve bilgi düzeylerine duyarlı olma, başkalarıyla etkileşim kurmadir.

Liderler hızla değişen çevrelere uyum sağlamak için eleştirel düşünmeye ihtiyaç duyarlar. Jenkins'e (2012) göre küresel liderler eleştirel düşünme becerilerine sahip olmalıdır. Küresel liderler, farklı kültürlerden 
gelen insanların kendilerinden başka inanç ve görüşlere sahip olabileceklerini kavrayabilmeleri için çeşitli kültürlere uyum sağlayabilmelidir. Singh ve Krishnan'a (2007) göre dönüşümcü liderlik kapsamlarından bir tanesi de eleştirel düşünmedir. Goryunova ve Jenkins'e (2017, s.80-82) göre üst biliş (metacognition) ile eleştirel düşünme yakından ilişkili ve birbirlerini tamamlayan kavramlardır. Day ve arkadaşları (2014, s.64-65) liderlerin gelişimi için üst biliş (metacognition) süreçlerinin öneminden bahsetmiştir. Küresel bağlamda liderlik eleştirel düşünmeyi gerektiriyorsa örgütler için eleştirel lider ihtiyacının olduğu söylenebilir. Jenkins ve Cutchens eleştirel liderliği şu şekilde tanımlamaktadır: Eleştirel liderlik, farklı durumlarda eleştirel düşünme becerilerinin liderlerin karar verme aşamalarına uygulanmasıdır (Jenkins ve Cutchens 2011, s. 6). Bu çalışmada geliştirilen ölçek bu tanım doğrultusunda şekillenmiştir. Eleştirel liderlik için 12 eylem geliştirmişlerdir. Bu eylemleri ise 4 gruba ayırmışlardır:

\section{Grup-1 (Durumsal liderlik ve bağlam)}

1- Durumun bağlamının farkında olma ve kararlarının etkilerini değerlendirme: Kararların, durum ve konunun eleştirel değerlendirilmesi sonucu verilmesi ile ilgilidir. İyice değerlendirilmeden hiçbir eyleme başlanmamalıdır (Jenkins ve Cutchens 2011, s.9). Örgütsel kararlar zaman, kaynak ve kişiler arası ilişkilerle doğrudan bağlantılı olduğu için karmaşıktır (Bolman ve Deal, 2017, s.27). Bu karmaşayı azaltabilmek adına liderlerin içinde bulundukları durumun neyi gerektirdiğinin farkında olmaları önemli olabilir.

2- Takipçilerinin güçlü ve zayıf yönlerini bilme, bu doğrultuda yönetme ve yetkilendirme: Lider takipçilerinin farklı davranış stilleri olabileceğini bilmeli ve her durumun farklı liderlik stili gerektirebileceğinin farkına varmalıdır. Durumsal liderlik, liderin stilini örgütün ve takımının durumuna göre uyarlaması gerektiğini vurgular (DuBois vd., 2015, s.32). Okul yöneticileri karar vermeden önce eleştirel bir değerlendirme yaparak kendi kurumlarının yapısını ve çalışanların özelliklerini belirleyebilir. 


\section{Grup-2 (Eylemler ve Karar verme)}

3- Karar verirken kurumun misyon ve değerlerini göz önünde bulundurma ve amaca yönelik olma: Liderler her zaman yaratıcı ve yenilikçi fikirlere sahip olmalıdır. Ancak, liderlerin bu fikirleri uygulamadan önce kültürel bağlamları da dikkate almaları kritik öneme sahiptir (Jenkins, 2012, s.99). Okullarda hedefe yönelik olmayan, herkesçe benimsenmiş bir amaç doğrultusunda yapılmayan eylemler öğretmenler tarafından gönülsüzce gerçekleştirilebilir ve bu iş gereksiz olarak nitelendirilebilir.

4- Değişime gitmeden önce süreçleri kavrama: Eleştirel liderlerin örgütün yapısını anlaması ve ondan sonra değişimin gerçekleştirilmesi gerektiğini vurgular. Değişim sürecinde kurum kültüründe değişimi göz ardı etmek, yeniliklerde paylaşılan değerleri ve normları hesaba katmamak değişim sürecinde yapılan önemli hatalardandır (Kotter, 1995, s.66).

\section{Grup-3 (Esneklik ve Açık Fikirlilik)}

5- Başkalarının karar, değer ve fikirlerindeki çeşitliliği anlamaya zaman ayırma: Çalışanların düşünce ve değerlerinin kabulü kurum bağlılıklarını arttırabilir. Burada asıl nokta liderin çalışanlarının fikirlerinin, inanışlarının ve değer yargılarının farklı olduğunu bilmesidir.

6- Karar verme süreçlerinde esnek ve açık fikirli olma: Esnek düşünebilen ve yeniliğe açık örgüt kültürü oluşturmada açık fikirlilik önemli bir yönetim aracıdır (Hernandez-Mogollon vd., 2010, s.371-372). Eleştirel lider olarak okul müdürleri hedefe ulaşmanın farklı yolları olabileceğinin farkına varmalıdır. Bu doğrultuda çalışanlarından gelebilecek fikirlere açık olmalı ve kendi yöntemlerini esnetebilmelidir.

7-Başkalarını olmalarını istediğin yerde değil oldukları yerde kabullenme ve kullanma: Çalışanların zayıf ve güçlü yönlerini bilme, onların gelişim süreçlerine hakim olmayı gerektirir. Onları hazır olmadıkları bir duruma zorlamak yerine, çalışanlar istenilen alanda gelişime teşvik edilmelidir (Jenkins ve Cutchens 2011, s.11). 


\section{Grup-4 (Eleştirel Liderlik)}

8- Yapıcı eleştiriyi kabul etme, içselleştirme ve uygulama: Eleştirilerle başa çıkma ve onları kabullenme sürecini vurgular. Eleştirel liderler aldıkları kararlara karşı takipçilerinin itirazlarını göz önünde bulundurmalıdırlar. Eleştirilmeyi kabul etmeyen bir lider ile eleştirel liderlik kavramı bir zıtlık olarak görülebilir. Llopis (2015), eleştirilmeyen bir liderin örgütün büyümesini ve yenilikleri keşfetmesini sağlayamayacağını belirtmiştir.

9- Karşı çıkmaya çalışmadan önce varsayımları değerlendirme: Eleştirel lider, mümkün olan tüm yolları değerlendirdiğinden ve planları her yönden incelediğinden emin olmalıdır. Okul müdürleri de varsayımları değerlendirerek karşılaşabilecekleri riskleri analiz edebilir ve onlara karşı önlemler alabilirler.

10- Sorular sorma ve uygun bir şekilde dinleme: Liderin iletişim becerilerinin iyi olmasıyla ilişkilidir. Bu madde liderin araştırmaya ve soruşturmaya açık olmasını tavsiye eder. Hackman ve Johnson (2013, s.22), etkili liderliğin etkili iletişim becerileri geliştirmeye bağlı olduğunu ve iletişim becerileri gelişmiş olan liderlerin başkalarını etkileme konusunda daha başarılı olabileceğini ifade etmiştir.

11- Eleştirel düşünmeyi teşvik etme: Örgütlerde eleştirel düşünme ortamı yaratmayı vurgular. Önce lider eleştirel düşünme becerilerine sahip olmalı daha sonra ise tüm paydaşları bu doğrultuda teşvik etmelidir (Jenkins ve Cutchens 2011, s.9).

12- Bilgilendirildikten sonra harekete geçme: Eleştirel liderliğin sadece düşüncede kalmaması gerektiğini, düşünülen şeylerin aktif bir şekilde hayata geçirilmesi eğilimini ifade eder (Jenkins ve Cutchens 2011, s.14). Örgütün hedeflerine nasıl ulaştıracağını konusunda bilgili ve özgüvenli liderlerin takipçileri daha fazla çalışarak başarılı olma olasılıklarını arttıracaklardır (Yukl, 2010, s.262).

Eleştirel düşünme becerileri eğitim örgütlerinde özellikle liderler için büyük önem taşımaktadır. Eleştirel düşünme becerilerine sahip olan okul liderlerinin etkili yönetim ve hedeflere ulaşma açısından başarı yakalayabilmesi daha olasıdır. Jenkins ve Cutchens (2011), liderlerin eleştirel düşünme becerilerinin olabildiğince esnek olması gerektiğini vurgulamışlardır. Okul yöneticilerinin eleştirel düşünme becerilerine sahip olması ve bunu liderlik stili olarak okul yönetim süreçlerinde uygulaması 
okulun etkili ve başarılı olmasına katkı sağlayabilir. Bu nedenle okul yöneticilerinin eleştirel liderlik stillerini geçerli ve güvenilir bir şekilde ölçebilecek bir ölçme aracına ihtiyaç duyulmaktadır. Türkiye'de eğitim yöneticilerinin eleştirel liderlik stilini ölçebilecek bir adet ölçme aracı bulunmaktadır. Saylık (2015) tarafından geliştirilen bu ölçek, okul yöneticilerinin eleştirel liderlik yeterliklerini ölçmektedir. Ancak yöneticilerin özellikle liderlik uygulamalarında eleştirel düşünme eylemlerini bir liderlik stili olarak ölçebilecek bir ölçme aracı bulunmamaktadır. Literatürde eleştirel liderlik alanındaki çalışmaların ve eleştirel liderlik stili ölçeğinin sınırlılığı eleştirel liderlik stili ölçeğini geliştirme ihtiyacını doğurmuştur. Geliştirilen ölçme aracı okul yöneticilerinin eleştirel liderlik stillerini ölçmeyi amaçlamaktadır.

\section{Yöntem}

Bu bölümde araştırmanın modeli, evren ve örneklemi, veri toplama araçları ve bunların uygulanması ile ilgili bilgiler sunulmuştur. Ayrıca veri toplama araçları kullanılarak toplanan verilerin çözümlenmesine ilişkin bilgilere yer verilmiştir.

\section{Araştırma Modeli}

$\mathrm{Bu}$ araştırmada eleştirel liderlik stili ölçeğinin geliştirilmesi amaçlanmış ve bu amaca uygun olarak tarama modeli kullanılmıştır. Tarama modeli, geniş grupların ve çeşitli toplulukların görüşleri alındı̆̆ı, özelliklerinin ve tutumlarının belirlendiği modelleridir (Büyüköztürk, vd., 2016).

\section{Çalışma Grubu}

Araştırmada üç farklı çalışma grubu bulunmaktadır.

\section{Çalışma Grubu 1}

Açımlayıc faktör analizi için veri toplanan gruptur. 2017-2018 eğitim öğretim yılında İstanbul ili Güngören ilçesi Milli Eğitim Müdürlüğüne bağlı 
devlet okullarının ilkokul, ortaokul ve lise kademelerinde görev yapmakta olan 360 öğretmen oluşturmaktadır (Tablo 1).

Tablo 1. Açımlayıcı Faktör Analizi Uygulanan Çalışma Grubunun Demografik Özellikleri

\begin{tabular}{llll}
\hline & Gruplar & $\boldsymbol{F}$ & $\mathbf{\%}$ \\
\hline \multirow{2}{*}{ Cinsiyet } & Kadın & 211 & 58.6 \\
& Erkek & 149 & 41.4 \\
\hline \multirow{4}{*}{ Kıdem } & 5 y1l ve altı & 118 & 32.8 \\
& 6-10 yıl arası & 87 & 24.2 \\
& 11-15yıl arası & 68 & 18.9 \\
& 16-20 yıl arası & 46 & 12.8 \\
& 21 yıl ve üstü & 41 & 11.4 \\
\hline \multirow{2}{*}{ Ĕitim } & Lisans & 315 & 87.5 \\
Durumu & Lisansüstü & 45 & 12.5 \\
\hline Toplam & & 360 & 100 \\
\hline
\end{tabular}

Tablo 1'de görüldüğü üzere, çalışmaya katılanların 211'i (\%58) kadın 149 'u (\%41) erkektir. Çalışmaya katılanların eğitim durumları değişkenine göre 315'i $(\% 87,5)$ Lisans ve 45'i $(\% 12,5)$ Lisans üstü eğitim düzeyine sahiptir. Çalışmaya katılanların öğretmenlik mesleğindeki kıdem yılları değişkenine göre 5 yıl ve altı mesleki kıdeme sahip olanların sayısı 118 (\%32,8), 6-10 yıl arası mesleki kıdeme sahip olanların sayısı 87 (\%24,2), 11-15 yıl arası mesleki kıdeme sahip olanların sayı1sı 68 (\%18,9),1620 yıl arası mesleki kıdeme sahip olanların sayısı 46 (\%12,8), 21 yıl ve üstü mesleki kıdeme sahip olanların sayısı ise $41(\% 11,4)$ olarak belirlenmiştir.

Çalışma Grubu 2; Doğrulayıc faktör analizi için veri toplanan gruptur. 2017-2018 eğitim öğretim yılında İstanbul ili Güngören ilçesi Milli Eğitim Müdürlüğüne bağlı devlet okullarının ilkokul, ortaokul ve lise kademelerinde görev yapmakta olan 349 öğretmen oluşturmaktadır.

Tablo 2'de görüldüğü üzere, çalışmaya katılanların \%55.9'i (195) kadın, \%44.1'i (154) erkektir. \%90.5'i (316) lisans, \%9.5'i (33) lisans üstü mezunudur. Öğretmenlik mesleğindeki kıdem yılları değişkenine göre 5 yıl ve altı mesleki kıdeme sahip olanların sayısı 75 (\%21.5), 6-10 yıl arası mesleki kıdeme sahip olanların sayısı 98 (\%28.1), 11-15 yıl arası mesleki kıdeme 
sahip olanların sayısı 77 (\%22.1), 16-20 yıl arası mesleki kıdeme sahip olanların sayısı 57 (\%16.3), 21 yıl ve üstü mesleki kıdeme sahip olanların sayısı ise 42 (\%12.0) olarak belirlenmiştir.

Tablo 2. Doğrulayıcı Faktör Analizi Uygulanan Çalışma Grubunun Demografik Özellikleri

\begin{tabular}{llll}
\hline & Gruplar & $f$ & $\%$ \\
\hline \multirow{2}{*}{ Cinsiyet } & Kadın & 195 & 55.9 \\
& Erkek & 154 & 44.1 \\
\hline \multirow{4}{*}{ Kıdem } & 5 y1l ve altı & 75 & 21.5 \\
& 6-10 yıl arası & 98 & 28.1 \\
& 11-15yı arası & 77 & 22.1 \\
& 16-20 yıl arası & 57 & 16.3 \\
\hline Ĕgitim & 21 yll ve üstü & 42 & 12.0 \\
Durumu & Lisans & 316 & 90,5 \\
Toplam & Lisansüstü & 33 & 9,5 \\
\hline
\end{tabular}

Çalışma Grubu 3; Test-tekrar test uygulamasının gerçekleştirildiği gruptur. 2017-2018 eğitim öğretim yılında İstanbul ili Güngören ilçesinde lise kademesinde görev yapan 38 öğretmenden oluşmaktadır.

Tablo 3. ELS Test-Tekrar Test Uygulaması Yapilan Katılımcilarn Demografik Özellikleri

\begin{tabular}{llll}
\hline & Gruplar & $f$ & $\%$ \\
\hline \multirow{2}{*}{ Cinsiyet } & Kadın & 18 & 47.4 \\
& Erkek & 20 & $52 . .6$ \\
\hline \multirow{4}{*}{ Kıdem } & 5 y1l ve altı & 16 & 42.1 \\
& 6-10 yıl arası & 10 & 26.3 \\
& 11-15yıl arası & 06 & 15.8 \\
& 16-20 yll arası & 04 & 10.5 \\
& 21 yıl ve üstü & 02 & 5.3 \\
\hline Eğitim & Lisans & 32 & 84.2 \\
Durumu & Lisansüstü & 6 & 15.8 \\
\hline Toplam & & 38 & 100 \\
\hline
\end{tabular}

Tablo 3'te görüldüğü üzere test-tekrar test uygulamasına katılanların $\% 47,4$ 'i (18) erkek, \%52,6'sı (20) kadın katılımcılardan oluşmaktadır. Katılımcıların eğitim durumları değişkenine göre 32'si $(\% 84,2)$ Lisans ve 
$6($ 's1 \%15,8) Lisans üstü eğitim düzeyine sahiptir. K1dem yılları değişkenine göre 5 yıl ve altı mesleki kıdeme sahip olanların sayısı 16 (\%42,1), 6-10 yıl arası mesleki kıdeme sahip olanların sayısı 10 (\%26,3), 1115 yıl arası mesleki kıdeme sahip olanların sayısı $6(\% 15,8), 16-20$ yıl arası mesleki kıdeme sahip olanların sayısı 4 (\%10,5), 21 yıl ve üstü mesleki kıdeme sahip olanların sayısı ise $2(\% 5,3)$ olarak belirlenmiştir.

\section{Veri Toplama Araçları}

\section{Liderlik Stilleri Ölçeği}

Geliştirilen eleştirel liderlik stili ölçeğinin ölçüt geçerliliğine kanıt sağlamak amacıyla Liderlik Stilleri Ölçeği kullanılmıştır. Liderlik Stilleri Ölçeği, öğretmen görüşleri doğrultusunda okul yöneticilerinin liderlik stillerini ölçmektedir. Akan, Yıldırım ve Yalçın (2014) tarafından geliştirilen ölçek 35 maddeden ve dönüşümcü, sürdürümcü ve serbest bırakıcı liderlik stili alt boyutlarından oluşmaktadır.

\section{Eleştirel Liderlik Stili Ölçeği}

Ölçeğin geliştirilmesine literatür taraması ile başlanmıştır. “Eleştirel liderlik" kavramı operasyonel olarak; eleştirel düşünme becerilerini liderin gözlemlenebilir eylemlerinde kullanması ve liderlik kararlarına uygulaması olarak tanımlanmıştır. Bu süreçte literatürde yer alan eleştirel, eleştirel liderlik, eleştirel düşünme ve eğilimleri incelenmiştir. Öncelikle Jenkins ve Cutchens'in (2011) "Leading Critically" isimli çalışmaları incelenmiştir. Bir gömülü teori olan bu çalışmada Ennis (1993) tarafında önerilen 10 eleştirel düşünme eylemi, liderlik eylemlerine uyarlanmıştır ve bunun sonucunda eleştirel liderlik için gerekli olan 12 eylem belirlenmiştir. Jenkins ve Cutchens (2011) tarafından belirlenen 12 eleştirel liderlik eylemi incelenmiş ve her eylem için maddeler yazılmıştır. Madde havuzu oluşturulduktan sonra 41 maddelik taslak ölçek formuna ulaşılmıştır. Bu maddeler bir Rehber öğretmeni, iki Türkçe öğretmeni ve bir Rehberlik ve Psikolojik danışmanlık doktora öğrencisi tarafından incelenmiştir. Geribildirimler dikkate alınmış ve bazı maddeler düzenlenmiştir. Ölçme ve geliştirme uzmanlarına ve eleştirel düşünme alanında 
çalışmalara yapan uzmanlara "uygun", "düzeltilmeli" ve "uygun değil" ifadelerinden oluşan bir form gönderilmiştir. Tüm bu işlemler sonucunda ve uzman görüşleri doğrultusunda madde sayısı 36'ya düşürülmüştür. Faktör analizi sonucunda ise ölçeğin son hali 30 madde olarak belirlenmiştir. Maddeler çıkarılırken ölçeğin kapsam geçerliliğini kaybetmemesine özen gösterilmiştir. Kapsam geçerliği, bir ölçme aracını oluşturan maddelerin ölçeğin ölçmek istediği nitelikleri yeterli bir şekilde temsil edebilme gücü ile ilgilidir (Seçer, 2015, s.18).

Ölçeğin formu 5'li likert olarak belirlenmiştir. (1) Hiçbir Zaman, (2) Nadiren, (3) Genellikle, (4) Çoğunlukla, (5) Her Zaman ifadeleri ölçekte yer almıştır. Likert ölçekleri, bireyin ilgili duruma ne derecene katıldığını belirtmesine imkân sağlarlar (Seçer, 2015, s. 13). Ölçekte bulunan maddelerin hepsi olumludur.

\section{Verilerin Çözümlenmesi}

Verilerin faktör analizine uygun olup olmadığını belirlemek amacıyla normallik testi, Kaiser-Meyer-Olkin (KMO) ve Bartlett Küresellik Testi (Bartlett test of Sphericity) yapılmıştır. Verilerin faktör analizine uygun olduğu görülmüş, 30-maddelik dört faktörlü bir yapı ortaya çıkmıştır. Sonrasında ise madde-toplam puan arasındaki korelasyon ve ölçüt geçerlik katsayıları hesaplanmıştır. Ortaya çıkan yapıyı test etmek için doğrulayıcı faktör analizi (DFA) uygulanmıştır.

Modelin doğrulandığı sonucuna ulaşabilmek için uyum değerleri dikkate alınmıştır. Ki-Kare değerinin $\left(\chi^{2}\right)$, serbestlik derecesine $(d f)$ oranı 2 veya daha küçük olursa ideal uyum, 2-5 arasında olursa kabul edilebilir uyum düzeyinde olduğu anlaşılır. (Comparative Fit Index) CFI uyum değeri 1 olursa ideal, 0.90-0.99 arasında olursa kabul edilebilir uyum olarak değerlendirilir. RMSEA (Root mean square error of approximation) uyum değerinin 0.05-0.09 arasında olması kabul edilebilir uyum olduğunun göstergesidir. RMR (Root mean square residuals) değerinin ideal uyum olarak değerlendirilebilmesi için 0 olması, kabul edilebilir olarak değerlendirilebilmesi için ise 1-5 arasında olması beklenir (Özdamar, 2016, s.185-186). 
Ölçeğin güvenirlik çalışmaları doğrultusunda Cronbach Alfa güvenirlik katsayısı, madde-toplam puan ve madde-kalan puan arasındaki korelasyon değerleri hesaplanmış, maddelerin alt ve üst grupları ayırt edip etmediğini tespit etmek için \%27'lik üst-alt bağımsız grup t-testi (Independent Samples t Test) uygulanmıştır. Ölçeğin kararlılık anlamında güvenirliliğine kanit sunmak için test-tekrar test uygulamasından elde edilen verilerin korelasyonu katsayıları hesaplanmıştır.

\section{Bulgular}

\section{Geçerlik Çalışmalan ile İlgili Bulgular}

Ölçeğin geçerliğine ilişkin bulguların ortaya çıkarılması için Açımlayıcı Faktör Analizi (AFA) ve Doğrulayıcı Faktör Analizi (DFA) yapılmıştır. Bu süreçte verilerin analizinde SPSS ve AMOS programlarından yararlanılmıştır.

Açımlayıcı Faktör Analizi (AFA), ölçme aracında bulunan maddelerin alt faktörlerinin belirlenmesinde ve maddeler arasındaki ilişkilerin saptanmasında kullanılan bir tekniktir (Sönmez ve Alacapınar, 2016, s.63). Verilerin faktör analizine uygunluğunun ve örneklem büyüklügünün yeterli olup olmadı̆̆ının belirlenebilmesi adına Kaiser-Meyer-Olkin (KMO) testi kullanılmıştır. Değişkenler arasında yeterli ilişkinin olup olmadığının belirlenebilmesi amacıyla ise Barlett's Küresellik Testi kullanılmıştır (Özdamar, 2016, s.150). Elde edilen sonuçlar aşağıda mevcut olan Tablo 4'te sunulmuştur.

Tablo 4. ELS'nin KMO ve Barlett's Küresellik Testi Sonuçlan

\begin{tabular}{llc}
\hline KMO and Bartlett's Test & & \\
\hline $\begin{array}{l}\text { Kaiser-Meyer-Olkin Measure of Sampling } \\
\text { Adequacy }\end{array}$ & & .967 \\
\hline & $\begin{array}{l}\text { Approx. } \\
\text { Chi-Square }\end{array}$ & $10.409,150$ \\
\cline { 2 - 3 } Bartlett's Test of Sphericity & Df & 630 \\
\cline { 2 - 3 } & Sig. & .000 \\
\hline
\end{tabular}


Tablo 4 görüldüğü üzere Eleştirel Liderlik Stili Ölçeği'nin (ELS) KMO değeri 0.50'nin üzerinde olduğundan ve Barlett's testi de 0.05 önem derecesinde anlamlı olduğundan veriler faktör analizine uygun bulunmuştur. Özdamar (2016, s.150), KMO değerlerinin 0.50'den büyük olması gerektiğini ve değerin 1 değerine yaklaştıkça mevcut ölçeğin olguyu ölçmede yüksek yeterlilikte bir ölçek olacağını vurgulamıştır [(KMO=0.967), Barlett's test $(630)=10409.150 \mathrm{p}=.000)]$.

Tablo 5'te özdeğeri 1'den büyük olan faktörler ve bu faktörlerin açıkladıkları varyans oranları verilmiştir.

Tablo 5. ELS'nin Alt Faktörleri Tarafından Açıklanan Varyans Oranları ve Özdeğerleri

\begin{tabular}{llll}
\hline Faktörler & Özdeğer & Varyans & Yığılmalı Varyans \\
\hline 1 & 19.024 & 52.846 & 52.846 \\
2 & 1.909 & 5.303 & 58.148 \\
3 & 1.300 & 3.610 & 61.758 \\
4 & 1.232 & 3.421 & 65.180 \\
\hline
\end{tabular}

Tablo 5'te görüldüğü gibi ELS'nin alt faktörleri tarafından açıklanan varyans oranları özdeğeri 19.024 olan birinci faktörün açıkladığı varyans oranı \% 52.846; özdeğeri 1.909 olan ikinci faktörün açıkladığı varyans oranı \% 5.303; özdeğeri 1.300 olan üçüncü faktörün açıladığı varyans oranı \% 3.610; özdeğeri 1.232 olan dördüncü faktörün açıkladığı varyans oranı \% 3.421 'dir. Faktör analizinde bir alt boyutun özdeğerinin 1'in üstünde olması beklenir (Seçer, 2015, s.85).

Maddelerin faktörlere dağılımının belirlenebilmesi amacıyla Varimax dik döndürme analizi yapılmıştır. Faktör yük değeri maddelerin alt boyutlarla olan ilişkisini açıkladığından madde faktör yükleri 0.40 ve 0.45 arasında olması önerilmektedir (Sönmez ve Alacapınar, 2016, s.70). $\mathrm{Bu}$ araştırma da madde yükü kestirim noktası 0.45 alt sınır olarak alınmış ve iki faktöre birden binişik olan maddelerin madde yük değerleri arasındaki farkın 0.10 'dan büyük olmasına özen gösterilmiştir. Faktör yük 0.45 'den küçük olan ve iki faktöre birden madde yükü veren ve aralarında 0.10'dan küçük fark olan 6 madde çıkarılmıştır $(14,20,22,34,35,36)$. Bu işlemin sonucunda 30 maddeden oluşan ölçeğin faktör yük değerleri, faktörlerin açıkladıkları varyans oranları ve madde numaraları aşağıda verilen Tablo 6'da sunulmuştur. 
Tablo 6. Açımlayıcı Faktör Analizi Sonuçları

\begin{tabular}{|c|c|c|c|c|}
\hline \multirow[t]{2}{*}{ Madde no } & \multicolumn{4}{|c|}{ Faktör Yük Değerleri } \\
\hline & $\begin{array}{l}\text { Açık } \\
\text { Fikirlilik }\end{array}$ & Durumsallık & $\begin{array}{l}\text { Araştır- } \\
\text { macılık }\end{array}$ & $\begin{array}{l}\text { Gelişime } \\
\text { odaklanma }\end{array}$ \\
\hline 32 & .732 & & & \\
\hline 31 & .725 & & & \\
\hline 30 & .723 & & & \\
\hline 29 & .720 & & & \\
\hline 27 & .710 & & & \\
\hline 33 & .707 & & & \\
\hline 26 & .685 & & & \\
\hline 24 & .666 & & & \\
\hline 23 & .646 & & & \\
\hline 28 & .624 & & & \\
\hline 25 & .592 & & & \\
\hline 17 & & .691 & & \\
\hline 18 & & .678 & & \\
\hline 19 & & .622 & & \\
\hline 1 & & .620 & & \\
\hline 21 & & .613 & & \\
\hline 15 & & .604 & & \\
\hline 4 & & .589 & & \\
\hline 16 & & .579 & & \\
\hline 3 & & .550 & & \\
\hline 2 & & .482 & & \\
\hline 7 & & & .784 & \\
\hline 6 & & & .734 & \\
\hline 8 & & & .688 & \\
\hline 5 & & & .653 & \\
\hline 9 & & & .600 & \\
\hline 12 & & & & .779 \\
\hline 13 & & & & .754 \\
\hline 11 & & & & .693 \\
\hline 10 & & & & .619 \\
\hline
\end{tabular}

Tablo 6 incelendiğinde ölçeği oluşturan maddelerin özdeğeri 1'den büyük 4 faktör altında toplandığı görülmektedir. Alt boyutlara ati maddeler incelenerek alt boyutlar isimlendirilmiştir. "Açık fikirlilik ve Esneklik" faktörü 11 maddeden $(1,2,3,4$, 5, 6, 7, 8, 9, 10, 11), "Eleștirel Karar Alma ve Eylemler" faktörü 10 maddeden (12, 13, 14, 15, 16, 17, 18, 19, 20, 21), 
"Araştırmacılık ve İletişim” faktörü 5 maddeden $(22,23,24,25,26)$, "Gelişime Odaklanma ve Karar verme" faktörü 4 maddeden $(27,28,29$, 30) meydana gelmiştir.

ELS'nin yapı geçerliği kapsamında faktörlerin kendi aralarında olan ve toplam ölçekle olan korelasyonları incelenmiştir. Elde edilen sonuçlar Tablo 7'de sunulmuştur.

Tablo 7. ELS'nin Yapı Geçerliği Uygulaması Yapılan Çalışma Grubundan Elde Edilen Verilerin Korelasyon Değerleri

\begin{tabular}{|c|c|c|c|c|}
\hline Faktör adı & $\begin{array}{l}\text { Açık } \\
\text { fikirlilik } \\
\text { ve esneklik }\end{array}$ & \begin{tabular}{l}
\multicolumn{2}{l}{ Eleştirel } \\
Karar Alma \\
ve Eylemler
\end{tabular} & $\begin{array}{l}\text { Araştır- } \\
\text { macılık } \\
\text { ve iletişim } \\
\end{array}$ & $\begin{array}{l}\text { Gelişime } \\
\text { odaklanma } \\
\text { ve karar alma }\end{array}$ \\
\hline $\begin{array}{l}\text { Açık } \\
\text { fikirlilik } \\
\text { ve esneklik }\end{array}$ & 1 & & & \\
\hline $\begin{array}{l}\text { Eleştirel } \\
\text { Karar Alma ve } \\
\text { Eylemler }\end{array}$ & $.766^{* *}$ & 1 & . & \\
\hline $\begin{array}{l}\text { Araştırmacilık } \\
\text { ve İletişim }\end{array}$ & $.703^{* *}$ & $.782^{* *}$ & 1 & \\
\hline $\begin{array}{l}\text { Gelişime } \\
\text { odaklanma } \\
\text { ve karar alma }\end{array}$ & $.672^{* *}$ & $.722^{* *}$ & $.770^{* *}$ & 1 \\
\hline Toplam puan & $.918^{* *}$ & $.931^{* *}$ & $.867^{* *}$ & $.821^{* *}$ \\
\hline $\mathrm{N}=359$, $^{* *} \mathrm{P}<.01$ & & & & \\
\hline
\end{tabular}

Tablo 7'de görüldüğü üzere faktörler arası korelasyonlar .672 ile .782, faktörler ile ölçek toplam puan arasındaki korelasyonlar ise .821 ile .931 arasında değişen pozitif yönde anlamlı değerler almıştır ( $\mathrm{p}<.01)$. Bu bulgu, ELS ölçeğini oluşturan faktörler ve faktör-toplam ölçek puanları arasında pozitif ve anlamlı bir ilişki olduğu yönünde yorumlanmıştır. Alt boyutların bir bütün olarak ELS'yi ölçtüğü söylenebilir.

Açımlayıcı faktör analizi sonucundaki 4 faktör ve 30 maddeden oluşan yapı, doğrulayıcı faktör analizi ile doğrulanmıştır. DFA yapı geçerliliği için vazgeçilmez bir araçtır (Brown, 2015, s.2). Doğrulayıcı faktör analizi sonucunda aşağıda yer alan Şekil 1 ortaya çıkmıştır. Şekil 1'de modele ilişkin faktör yüklerine, maddeler ve alt boyutlar arasındaki korelasyon katsayılarına, Ki-Kare değerine ve serbestlik derecesine yer verilmiştir. 


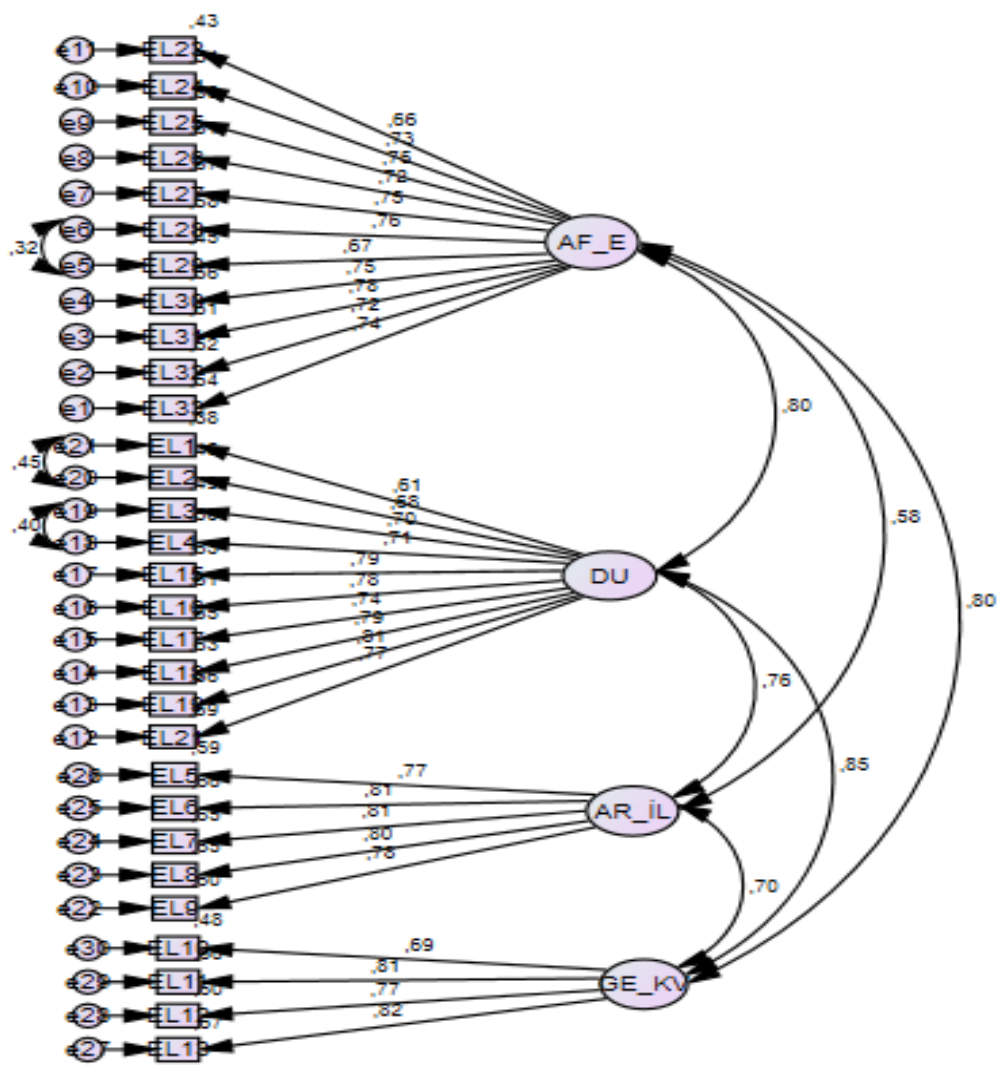

chi-square $=967,884 \mathrm{df}=396 \mathrm{p}=, 000$

Şekil 2. Doğrulayıcı Faktör Analizi

Şekil 1, modelin uygunluğunu ve maddeler arasındaki korelasyonun iyi düzeyde olduğunu göstermektedir $\left(\chi^{2}=967.884 ; \mathrm{sd}=396 ; \mathrm{p}<.01\right)$. Şekil 1 'de maddeler ile alt boyutlar arasındaki korelasyon katsayılarının .61 ile .82 arasında değişim gösterdiği gözlenmiştir. Alt boyutların kendi aralarındaki korelasyonları ise .58 ile .85 arasında değişmektedir.

Modelin doğrulandığı sonucuna ulaşabilmek için uyum değerleri dikkate alınmıştır. Ki-Kare değerinin $\left(\chi^{2}\right)$, serbestlik derecesine (df) oranı 2 veya daha küçük olursa ideal uyum, 2-5 arasında olursa kabul edilebilir uyum düzeyinde olduğu anlaşlır. (Comparative Fit Index) CFI uyum değeri 1 olursa ideal, 0.90-0.99 arasında olursa kabul edilebilir uyum olarak değerlendirilir. RMSEA (Root mean square error of approximation) uyum 
değerinin 0.05-0.09 arasında olması kabul edilebilir uyum olduğunun göstergesidir. RMR (Root mean square residuals) değerinin ideal uyum olarak değerlendirilebilmesi için 0 olması, kabul edilebilir olarak değerlendirilebilmesi için ise 1-5 arasında olması beklenir (Özdamar, 2016, s. 185186). Ki-Kare değerinin $\left(\chi^{2}\right)$, serbestlik derecesine (df) oranı $\left(\chi^{2} / \mathrm{sd}\right.$; 967.884/396=2.44) kabul edilebilir uyum; CFI uyum değeri (.92) kabul edilebilir uyum; RMSEA uyum değeri (.06) kabul edilebilir uyum; RMR (.038) değerinin ideal uyum düzeyinde olduğu görülmüştür.

ELS'nin ölçüt geçerliği hakkında bilgi edinmek için daha önce güvenirliği ve geçerliği kanıtlanmış, Akan, Yıldırım ve Yalçın (2014) tarafından geliştirilen Okul Müdürlerinin Liderlik Stilleri Ölçeği temel alınmıştır. Sonuçlar Tablo 8'de sunulmuştur.

Tablo 8. ELS ile OMLSÖ Arasındaki İlişkiler

\begin{tabular}{llll}
\hline Boyut & $\begin{array}{l}\text { Dönüşümcü } \\
\text { liderlik }\end{array}$ & $\begin{array}{l}\text { Serbest } \\
\text { Birakıcı Liderlik }\end{array}$ & $\begin{array}{l}\text { Sürdürümcü } \\
\text { Liderlik }\end{array}$ \\
\hline $\begin{array}{l}\text { Açık fikirlilik } \\
\text { ve esneklik }\end{array}$ & $.676^{* *}$ & -.274 & -.200 \\
\hline $\begin{array}{l}\text { Eleştirel Karar } \\
\text { Alma ve Eylemler }\end{array}$ & $.671^{* *}$ & $-.360^{* *}$ & -.176 \\
\hline $\begin{array}{l}\text { Araştırmacıllk } \\
\text { ve İletişim }\end{array}$ & $.618^{* *}$ & $-.326^{*}$ & -.025 \\
\hline $\begin{array}{l}\text { Gelişime odaklanma ve } \\
\text { karar verme }\end{array}$ & $.518^{* *}$ & -.274 & -.043 \\
\hline $\begin{array}{l}\text { Eleştirel Liderlik } \\
\text { Toplam }\end{array}$ & $.696^{* *}$ & $-.335^{*}$ & -.153 \\
\hline *p<.05; **p<.01 & & & \\
\hline
\end{tabular}

Tablo 8 incelendiğinde, Okul Müdürlerinin Liderlik Stilleri Ölçeğinin Dönüşümcü Liderlik boyutu ile ELS toplam puanı ve alt boyutları arasında pozitif yönde; Okul Müdürlerinin Liderlik Stilleri Ölçeğinin Serbest Bırakıcı Liderlik boyutu ile ELS toplam puanı ve Eleştirel Karar Alma ve Eylemler ve Araştırmacılık ve İletişim alt boyutları arasında negatif yönde 
anlamlı ilişki bulunmuştur. Okul Müdürlerinin Liderlik Stilleri Ölçeğinin Sürdürümcü Liderlik boyutu ile ELS toplam puanı ve alt boyutları arasında anlamlı ilişki bulunmamaktadır ( $\mathrm{p}>.05)$. ELS'nin alt boyutları ile Dönüşümcü ve Serbest Bırakıcı Liderlik Stilleri ile anlamlı ilişkili olduğu ve bu sonucun ölçüt geçerliliği açısından yeterli olarak görülebileceği söylenebilir.

\section{Güvenirlik Çalışması ile İlgili Bulgular}

Ölçeğin güvenirliği ile ilgili Cronbach Alfa güvenirlik katsayıları, maddetoplam ve madde kalan korelasyonu, üst \%27 ve alt \%27'lik gruplar arasında yapılan bağımsız gruplar t-testi, test-tekrar test korelasyon ve bağımsız gruplar t- testi analizleri yapılmıştır. Tablo 9' da alt boyutlara ve ölçeğin geneline ait Cronbach-Alfa iç tutarlılık katsayıları verilmiştir.

\section{Tablo 9. Cronbach Alfa Güvenirlik Katsayıları}

\begin{tabular}{ll}
\hline Faktör adı & Cronbach-Alfa İç Tutarlılık Katsayıları \\
\hline Açık fikirlilik ve esneklik & $\mathbf{. 9 4 2}$ \\
Eleştirel Karar Alma ve Eylemler & $\mathbf{. 9 2 2}$ \\
Araştırmacılık ve İletişim & $\mathbf{. 9 1 2}$ \\
Gelişime odaklanma ve &. $\mathbf{8 8 2}$ \\
karar alma & \\
Genel & .969 \\
\hline
\end{tabular}

Tablo 9'da görüldüğü üzere ölçeğin "Açık fikirlilik ve esneklik" alt boyutu güvenirlik katsayısı 0.94, "Eleştirel Karar Alma ve Eylemler" alt boyutu 0.92, "Araştırmacılık ve İletişim" alt boyutu 0.91, "Gelişime odaklanma ve karar alma" ise 0.88 olarak hesaplanmıştır. Genel güvenirlik katsayısı 0.969 olarak hesaplanmıştır.

Güvenirlik katsayıları hesaplandıktan sonra maddelerin ayırt ediciliğine karar verebilmek için madde-toplam ve madde-kalan korelasyon katsayıları hesaplanmış ve Tablo 10'da sunulmuştur. 
Tablo 10. Madde Kalan ve Madde Toplam Korelasyonlart

\begin{tabular}{|c|c|c|c|}
\hline Faktör Ad 1 & Madde No & Madde-Kalan & Madde-Toplam \\
\hline \multirow{11}{*}{$\begin{array}{l}\text { Açık fikirlilik ve Es- } \\
\text { neklik }\end{array}$} & 23 & .645 & .670 \\
\hline & 24 & .725 & .745 \\
\hline & 25 & .739 & .759 \\
\hline & 26 & .708 & .730 \\
\hline & 27 & .695 & .717 \\
\hline & 28 & .718 & .739 \\
\hline & 29 & .756 & .775 \\
\hline & 30 & .739 & .759 \\
\hline & 31 & .709 & .731 \\
\hline & 32 & .651 & .677 \\
\hline & 33 & .719 & .740 \\
\hline \multirow{10}{*}{$\begin{array}{l}\text { Eleştirel Karar Alma } \\
\text { ve Eylemler }\end{array}$} & 1 & .631 & .658 \\
\hline & 2 & .668 & .692 \\
\hline & 3 & .653 & .681 \\
\hline & 4 & .725 & .748 \\
\hline & 15 & .726 & .749 \\
\hline & 16 & .708 & .732 \\
\hline & 17 & .631 & .660 \\
\hline & 18 & .769 & .775 \\
\hline & 19 & .742 & .762 \\
\hline & 21 & .690 & .714 \\
\hline \multirow{5}{*}{$\begin{array}{l}\text { Araştırmacılık ve İle- } \\
\text { tişim }\end{array}$} & 5 & .740 & .761 \\
\hline & 6 & .741 & .762 \\
\hline & 7 & .705 & .729 \\
\hline & 8 & .719 & .741 \\
\hline & 9 & .720 & .741 \\
\hline \multirow{4}{*}{$\begin{array}{l}\text { Gelişime odaklanma } \\
\text { ve Karar Verme }\end{array}$} & 10 & .695 & .718 \\
\hline & 11 & .709 & .730 \\
\hline & 12 & .656 & .682 \\
\hline & 13 & .669 & .694 \\
\hline
\end{tabular}

Tablo 10'a göre madde-kalan katsayıları 0.631-0.742 arasında değişmektedir. Bu durumda mevcut maddelerin ölçülmesi hedeflenen olguyu iyi derecede ölçebileceği sonucuna varılabilir (Sönmez ve Alacapınar, 2016, s. 57). Maddelerin ayırt etme gücünün yeterliliğinin ölçülen özellik bağlamında belirlenebilmesi için madde-toplam korelasyon katsayıları hesaplanmıştır. Buna göre maddelerin madde-toplam korelasyon katsayıları 0.658 ile 0.775 arasında değişmektedir. Bu sonuç ölçekteki maddelerin ayırt etmede başarılı olduklarının göstergesidir 
(Büyüköztürk, 2014, s. 193). Madde-toplam ve madde-kalan korelasyonları anlamlıdır $(\mathrm{p}<.001)$.

Alt ve üst \%27'lik gruplarda bulunanların ortalamaları arasındaki farklılığı belirlemek için bağımsız gruplar t-testi analizler yapılmış ve Tablo 11'de gösterilmiştir.

Tablo 11. Üst \%27 ve Alt \%27'lik Gruplar Arasında Yapılan Bağımsız Gruplart-Testi Sonuçları

\begin{tabular}{|c|c|c|c|c|c|c|}
\hline Madde & Gruplar & $\mathbf{N}$ & Ort & Ss & $t$ & $\mathrm{p}$ \\
\hline \multirow{2}{*}{1} & Alt \%27 & 97 & 2.9381 & .82682 & \multirow{2}{*}{-13.063} & \multirow{2}{*}{.000} \\
\hline & Üst \%27 & 97 & 4.4021 & .73115 & & \\
\hline \multirow{2}{*}{2} & Alt $\% 27$ & 97 & 2.9485 & .83381 & \multirow{2}{*}{-13.711} & \multirow{2}{*}{.000} \\
\hline & Üst\%27 & 97 & 4.4443 & .67653 & & \\
\hline \multirow{2}{*}{3} & Alt $\% 27$ & 97 & 2.7320 & .87220 & \multirow{2}{*}{-14.575} & \multirow{2}{*}{.000} \\
\hline & Üst\%27 & 97 & 4.4330 & .74871 & & \\
\hline \multirow{2}{*}{4} & Alt \%27 & 97 & 2.7423 & .78100 & \multirow{2}{*}{-16.706} & \multirow{2}{*}{.000} \\
\hline & Üst\%27 & 97 & 4.5464 & .72199 & & \\
\hline \multirow{2}{*}{5} & Alt $\% 27$ & 97 & 2.8247 & .73613 & \multirow[t]{2}{*}{-19.976} & \multirow{2}{*}{.000} \\
\hline & Üst\%27 & 97 & 4.6701 & .53467 & & \\
\hline \multirow{2}{*}{6} & Alt $\% 27$ & 97 & 2.9381 & .83933 & \multirow{2}{*}{-19.193} & \multirow{2}{*}{.000} \\
\hline & Üst\%27 & 97 & 4.7835 & .43843 & & \\
\hline \multirow{2}{*}{7} & Alt \%27 & 97 & 3.0000 & .91287 & \multirow{2}{*}{-16.579} & \multirow{2}{*}{.000} \\
\hline & Üst \%27 & 97 & 4.7526 & .50064 & & \\
\hline \multirow{2}{*}{8} & Alt $\% 27$ & 97 & 2.9167 & .82929 & \multirow{2}{*}{-16.439} & \multirow{2}{*}{.000} \\
\hline & Üst\%27 & 97 & 4.6289 & .60069 & & \\
\hline \multirow{2}{*}{9} & Alt $\% 27$ & 97 & 2.7835 & .78032 & \multirow{2}{*}{-16.169} & \multirow{2}{*}{.000} \\
\hline & Üst\%27 & 97 & 4.4639 & .66241 & & \\
\hline \multirow{2}{*}{10} & Alt \%27 & 97 & 2.7732 & .75698 & & \\
\hline & Üst\%27 & 97 & 4.4330 & .70574 & -15.795 & .000 \\
\hline & Alt $\% 27$ & 97 & 2.8660 & .81175 & & \\
\hline 11 & Üst\%27 & 97 & 4.4742 & .61395 & -15.563 & .000 \\
\hline 12 & Alt \%27 & 97 & 2.7629 & .71841 & 12060 & 000 \\
\hline 12 & Üst\%27 & 97 & 4.4021 & .73115 & -13.063 & .000 \\
\hline & Alt \%27 & 97 & 2.7320 & .75713 & & \\
\hline 13 & Üst\%27 & 97 & 4.3196 & .71511 & -15.014 & .000 \\
\hline & Alt \%27 & 97 & 2.6495 & .89024 & 17180 & \\
\hline 15 & Üst\%27 & 97 & 4.5670 & .64400 & -17.188 & .000 \\
\hline 16 & Alt $\% 27$ & 97 & 2.8041 & .88552 & & \\
\hline 16 & Üst \%27 & 97 & 4.5876 & .65753 & -15.926 & .000 \\
\hline & Alt $\% 27$ & 97 & 2.6701 & .80002 & & \\
\hline 17 & Üst\%27 & 97 & 4.3608 & .76629 & -15.031 & .000 \\
\hline & Alt \%27 & 97 & 2.6082 & .76629 & & \\
\hline 18 & Üst\%27 & 97 & 4.5670 & .57567 & -20.273 & .000 \\
\hline
\end{tabular}




\begin{tabular}{|c|c|c|c|c|c|c|}
\hline 19 & $\begin{array}{l}\text { Alt \%27 } \\
\text { Üst\%27 }\end{array}$ & $\begin{array}{l}97 \\
97\end{array}$ & $\begin{array}{l}2.7010 \\
4.5052\end{array}$ & $\begin{array}{c}.76601 \\
.63120\end{array}$ & -17.902 & .000 \\
\hline \multirow{2}{*}{21} & Alt $\% 27$ & 97 & 2.6495 & .76432 & \multirow{2}{*}{-15.477} & \multirow{2}{*}{.000} \\
\hline & Üst\%27 & 97 & 4.4021 & .81214 & & \\
\hline \multirow{2}{*}{23} & Alt \%27 & 97 & 3.0000 & .70711 & \multirow{2}{*}{-15.149} & \multirow{2}{*}{.000} \\
\hline & Üst\%27 & 97 & 4.4742 & 64699 & & \\
\hline \multirow{2}{*}{24} & Alt $\% 27$ & 97 & 2.8557 & .61220 & \multirow{2}{*}{-20.976} & \multirow{2}{*}{.000} \\
\hline & Üst\%27 & 97 & 4.5876 & .53527 & & \\
\hline \multirow{2}{*}{25} & Alt $\% 27$ & 97 & 2.8454 & .76839 & \multirow{2}{*}{-17.121} & \multirow{2}{*}{.000} \\
\hline & Üst\%27 & 97 & 4.5361 & .59620 & & \\
\hline \multirow{2}{*}{26} & Alt $\% 27$ & 97 & 2.9485 & .83381 & \multirow{2}{*}{-15.756} & \multirow{2}{*}{.000} \\
\hline & Üst\%27 & 97 & 4.5979 & .60656 & & \\
\hline \multirow{2}{*}{27} & Alt $\% 27$ & 97 & 3.0309 & .82226 & \multirow{2}{*}{-15.415} & \multirow{2}{*}{.000} \\
\hline & Üst\%27 & 97 & 4.5979 & .57118 & & \\
\hline \multirow{2}{*}{28} & Alt $\% 27$ & 97 & 2.7732 & .72894 & \multirow{2}{*}{-16.994} & \multirow{2}{*}{.000} \\
\hline & Üst\%27 & 97 & 4.4536 & .64583 & & \\
\hline \multirow{2}{*}{29} & Alt $\% 27$ & 97 & 2.7732 & .81016 & \multirow{2}{*}{-17.022} & \multirow{2}{*}{.000} \\
\hline & Üst\%27 & 97 & 4.4948 & .57958 & & \\
\hline \multirow{2}{*}{30} & Alt $\% 27$ & 97 & 2.7629 & .76066 & \multirow{2}{*}{-17.360} & \multirow{2}{*}{.000} \\
\hline & Üst\%27 & 97 & 4.5062 & .63120 & & \\
\hline \multirow{2}{*}{31} & Alt \%27 & 97 & 2.8144 & .76825 & \multirow{2}{*}{-16.905} & \multirow{2}{*}{.000} \\
\hline & Üst\%27 & 97 & 4.4845 & .59710 & & \\
\hline \multirow{2}{*}{32} & Alt \%27 & 97 & 3.0206 & .94626 & \multirow{2}{*}{-15.182} & \multirow{2}{*}{.000} \\
\hline & Üst\%27 & 97 & 4.6907 & .52759 & & \\
\hline 33 & Alt $\% 27$ & 97 & 2.8860 & .79881 & -15 182 & 000 \\
\hline 30 & Üst\%27 & 97 & 4.5876 & .59077 & -10.102 & .000 \\
\hline
\end{tabular}

Tablo $11^{\prime}$ de görüldüğü üzere üst \%27'lik grubun aritmetik ortalamas1 4 ve 4'ün üzerinde iken, alt \%27'lik grubun aritmetik ortalaması 3 ve 3 'ün altında kalmaktadır. Maddelerin $\mathrm{t}$-değerlerinin anlamlı olduğu görülmektedir $(\mathrm{p}<.01)$. Madde ortalama puanlarıyla yapılan bağımsız gruplar t-testi sonuçlarına göre ölçekteki maddelerin güvenirliğinin yüksek olduğu ve puanlayıcıları, ölçülmek istenen özellikler bakımından ayırt edebildiği şeklinde yorumlanabilir (Büyüköztürk, 2014, s.39-47).

Uygulanan test-tekrar test yöntemi ile ölçeğin kararlılık anlamındaki güvenilirliği belirlenmiştir. Tekrar-tekrar test, ilk test yapıldıktan üç hafta sonra uygulanmıştır. Test-tekrar test uygulaması 38 öğretmenle gerçekleştirilmiştir. Tablo 12' de test-tekrar test korelasyon katsayıları verilmiştir. 
Tablo 12. Test-Tekrar Test Korelasyon Katsayıları

\begin{tabular}{llllll}
\hline Boyut & $\begin{array}{l}\text { Açık } \\
\text { Fikirlilik } \\
\text { ve Esneklik } \\
\text { (Son-test) }\end{array}$ & $\begin{array}{l}\text { Eleştirel } \\
\text { Karar Alma } \\
\text { ve Eylemler } \\
\text { (Son-test) }\end{array}$ & $\begin{array}{l}\text { Araştır- } \\
\text { macılık } \\
\text { ve Iletişim } \\
\text { (Son-test) }\end{array}$ & $\begin{array}{l}\text { Gelişime } \\
\text { odaklanma ve } \\
\text { Karar Verme } \\
\text { (Son-test) }\end{array}$ & $\begin{array}{l}\text { Toplam } \\
\text { Puan } \\
\text { (Son- } \\
\text { test) }\end{array}$ \\
\hline $\begin{array}{l}\text { Açık Fikirlilik } \\
\text { ve Esneklik } \\
\text { (Ön-Test) }\end{array}$ & $.823^{* *}$ & $.839^{* *}$ & $.703^{* *}$ & $.733^{* *}$ & $.859^{* *}$ \\
\hline $\begin{array}{l}\text { Eleştirel Karar } \\
\begin{array}{l}\text { Alma ve Eylem- } \\
\text { ler (Ön-Test) }\end{array}\end{array}$ & $.736^{* *}$ & $.884^{* *}$ & $.722^{* *}$ & $.725^{* *}$ & $.843^{* *}$ \\
\hline $\begin{array}{l}\text { Araştırmacılık } \\
\text { ve İletişim } \\
\text { (Ön-Test) }\end{array}$ & $.759^{* *}$ & $.821^{* *}$ & $.739^{* *}$ & $.683^{* *}$ & $825^{* *}$ \\
\hline $\begin{array}{l}\text { Gelişime } \\
\text { odaklanma } \\
\text { ve Karar Verme } \\
\text { (Ön-Test) }\end{array}$ & $.710^{* *}$ & $.799^{* *}$ & $.721^{* *}$ & $.701^{* *}$ & $.798^{* *}$ \\
\hline $\begin{array}{l}\text { Toplam } \\
\text { Puan (Ön-Test) }\end{array}$ & $.834^{* *}$ & $921^{* *}$ & & & $913^{* *}$ \\
\hline
\end{tabular}

Tablo 12'de görüldügüü üzere faktörlerin korelasyon katsayıları 0.701 ile 0.884 arasinda; toplam puan ile alt boyutların korelasyon katsayısı ise 0.78 ile 0.913 arasında olarak hesaplanmıştır. Bu sonuçlara göre ölçeğin kararlılık anlamındaki güvenilirliğinin yüksek düzeyde olduğu söylenebilir.

\section{Sonuç ve Tartışma}

Liderlik örgütlerin başarısında rol alan en önemli etmenlerden bir tanesi olarak görülmektedir. Okul müdürünün liderlik özelliğinin okul iklimini ve öğrencilerin başarısını belirlemede en önemli faktör olduğu ifade edilmektedir (Allen 1981'den akt., Vecchio, 2007). Eleştirel liderlik stiline sahip bir lider okullarda farklı düşüncelerin de kabul görmesini kolaylaştırıp ön yargıları engelleyebilir. Wood (2012, s.1), eleştirel 
düşünürlerin açık fikirli olması gerektiğini vurgulamıştır. Açık fikirli insanların bir şeyi araştırmadan kabul ya da reddetmeyeceğini, kendi bakış açılarına tamamen ters olan fikirleri dahi keşfetmeye istekli olduklarından bahsetmiştir. Açık fikirli ve esnek liderler eğitim örgütlerinde yaratacakları güven duygusuyla hoşgörüyü yaygınlaştırabilirler. $\mathrm{Bu}$ anlamda çalışmada Eleştirel Liderlik Ölçeği'nin (ELSÖ) geliştirilmesi ve ölçeğin geçerli ve güvenirliğine yöenlik kanıt sunmak amaçlanmıştır.

Literatürde Saylık (2015) tarafından geliştirilen "Eleştirel Liderlik Ölçeği" isimli okul müdürlerinin eleştirel liderlik yeterliliklerini ölçen 34 maddeden oluşan bir ölçek bulunmaktadır. Ölçek eleştirel liderlik özellikleri ve eleştirel yönetim uygulamaları olmak üzere 2 boyuta ayrılmış ve 5'li likert tipinde oluşturulmuştur. Bu araştırmada geliştirilen Eleştirel Liderlik Stili Ölçeği ise okul yöneticilerinin eleştirel liderlik stilleri düzeyini belirlemek amacını taşımaktadır. ELS, Eleştirel Liderlik Ölçeğinden farklı olarak Jenkins ve Cutchens'in (2011) "Leading Critically" isimli gömülü teori çalışmasında yer alan 12 eleştirel liderlik eylemi temel alınarak geliştirilmiştir ve 4 boyuta ayrılmıştır. ELS'nin alt boyutları Açık fikirlilik ve esneklik, Eleştirel Karar Alma ve Eylemler, Araştırmacılık ve İletişim, Gelişime odaklanma ve karar almadır.

Faktör analizine başlamadan önce KMO ve Barlett's testi değerleri incelenmiştir. Bu değerler, verilerin faktör analizine uygun olduğunun göstermiştir. Ölçeğin faktör sayısını tespit edebilmek için Açımlayıcı Faktör Analizi yapılmıştır. Ölçek maddelerinin özdeğeri 1'den büyük 4 faktör altında toplandığı görülmektedir. Bu araştırmada faktör yük değeri 0.45 alt sınır olarak alınmış ve faktör analizinin sonuçlarına bakıldığında bazı maddelerin faktör yük değerinin 0.45 'in altında kalanlar çıkarılmış ve bu işlemin sonucunda 30 maddeden oluşan ELS ölçeği son halini almıştır. ELS'nin yapı geçerliği kapsamında faktörlerin kendi aralarında olan ve toplam ölçekle olan korelasyonları incelenmiştir. ELS ölçeğini oluşturan faktörler ve faktör-toplam ölçek puanları arasında pozitif ve anlamlı bir ilişki olduğu belirlenmiştir. 4 faktörlü ölçeğin yapı geçerliğini test etmek amacıyla Doğrulayıcı Faktör Analizi yapılmıştır. Ki-Kare değerinin $\left(\chi^{2}\right)$, serbestlik derecesine (df) oran $\left(\chi^{2} / \mathrm{sd} ; 967.884 / 396=2.44\right)$ kabul edilebilir uyum; CFI uyum değeri (.92) kabul edilebilir uyum; RMSEA uyum değeri (.06) kabul edilebilir uyum; RMR (.038) değerinin ideal uyum düzeyinde olduğu görülmüştür. ELS'nin ölçüt geçerliği hakkında bilgi edinmek için 
daha önce güvenirliği ve geçerliği kanıtlanmış, Akan, Yıldırım ve Yalçın (2014) tarafindan geliştirilen Okul Müdürlerinin Liderlik Stilleri Ölçeği temel alınmıştır. Genel olarak ELS'nin alt boyutlarının Dönüşümcü liderlik stili ile pozitif ve orta düzeyde; serbest bırakıcı liderlik stili ile negatif yönde ve düşük düzeyde anlamlı ilişkili olduğu görülmüştür. Ölçüt geçerliliği açısından yeterli olduğu düşünülmüştür.

Ölçeğin güvenirliği belirlemek için Cronbach Alfa güvenirlik katsayıları hesaplanmış ve ölçeğin genel güvenirlik katsayısının 0.969 olduğu anlaşılmıştır. Sonrasında, maddelerin ayırt edici özelliğine kanıt oluşturmak için madde-toplam ve madde-kalan korelasyon katsayıları ve bağımsız gruplar $t$ testi hesaplanmış, mevcut maddelerin ölçülmesi hedeflenen olguyu iyi derecede ölçebileceği sonucuna varılmıştır. Testtekrar test korelasyon analizinde toplam puanların korelasyon katsayısı anlamlı ve yüksek düzeyde hesaplanmıştır. Bu sonuçlara göre ölçeğin kararlılık anlamındaki güvenilirliğinin yüksek düzeyde olduğu görülmüştür. Eleştirel Liderlik Stili Ölçeği'ne (ELSÖ) ait alt boyutlar ve madde dağılımları aşağıda verilmiştir:

Açık fikirlilik ve Esneklik: 1, 2, 3, 4, 5, 6, 7, 8, 9, 10, 11

Eleştirel Karar Alma ve Eylemler: 12, 13, 14, 15, 16, 17, 18, 19, 20, 21

Araştırmacılık ve İletişim: 22, 23, 24, 25, 26

Gelişime Odaklanma ve Karar verme: $27,28,29,30$

Ölçek, okul yöneticilerinin eleştirel liderlik stillerine ilişkin öğretmen algılarının belirlenmesinde kullanılabilir. Ölçeğe ilişkin geçerlik ve güvenirlik çalışmaları farklı örneklemlerle yapılabilir. 


\section{EXTENDED ABSTRACT}

\section{Critical Leadership Style Scale: Validity and Reliability Study

\author{
Cenk Aygün - Mustafa Özgenel \\ Ministry of National Education, Istanbul Sabahattin Zaim University
} \\ *}

Leaders need to think critically to adapt to the circulating environments. According to Jenkins (2012), global leaders should have critical thinking skills. According to Singh and Krishnan (2007), one of the transformational leadership scopes is critical thinking. According to Goryunova and Jenkins (2017), metacognition and critical thinking are closely related and complementary concepts. Day et al. (2014) mentioned the importance of metacognition processes for the development of leaders. If leadership in a global context requires critical thinking, it can be said that there is a need for a critical leader for organizations.

Having school principals' critical thinking skills and applying it as a leadership style in school management processes can contribute to the effective and successful school. In this sense, there is a need for a measurement tool that can measure the critical leadership styles of school principals in a valid and reliable way. In line with this need, the study aimed to develop the Critical Leadership Style Scale (CLSS) perceived by the teachers of the school principals and a relational model was used in accordance with this aim. The research was conducted in public schools in Güngören district of Istanbul province in the 2017-2018 academic years. In the research, data were collected from 360 teachers for exploratory factor analysis, 349 for confirmatory factor analysis and 38 teachers for test-retest.

The Leadership Styles Scale developed by Akan, Yıldırım and Yalçın (2014) was used to provide evidence for the criterion validity of the developed critical leadership style scale. The scale form was defined as 5-point Likert "(1) Never, (2) Rarely, (3) Generally, (4) Mostly, (5) Always". There is no reverse item in the scale. The Critical Leadership Style Scale (CLSS) was developed on the basis of 12 critical leadership actions in Jenkins and Cutchens' (2011) grounded theory which is named "Leading Critically". 
Since the KMO value $(\mathrm{KMO}=0.967)$ and Barlett's test (Barlett's $(\mathrm{df}=630$; x2=10409.150; $\mathrm{p}<.000$ ) of the Critical Leadership Style Scale were significant, the data were found appropriate for factor analysis.

In the factor analysis, firstly the principal components analysis was performed and then Varimax vertical rotation analysis was performed to determine the distribution of the items to the factors .In this research, the item load estimation point was taken as the lower limit of 0.45 and attention was paid to the difference between the item load values of the items which are connected to two factors to be greater than 0.10. Six items, with a factor load of less than 0.45 , which gave an item load to two factors at the same time and a difference of less than 0.10 were removed $(14,20,22,34,35,36)$ and 30 items remained on the scale.

The Eigen value of CLSS explains 4 factors with a value greater than 1 and 65.180 of the total variances. The first factor explained variance ratio was $52.846 \%$; second factor explained variance rate $5.303 \%$; the third factor explained the variance rate $3.610 \%$; the variance rate explained by the fourth factor is $3,421 \%$.

The Eigen values of the items were grouped under 4 factors. By examining the sub-dimensions; "Open-mindedness and Flexibility" (1, 2, 3, 4, 5, 6, 7, 8, 9, 10, 11), "Critical Decision Making and Actions" (12, 13, 14, 15, 16, 17, 18, 19, 20, 21), "Research and Communication" (22, 23, 24, 25, 26)," Focus on Development and Decision Making "(27, 28, 29, 30).

The correlation values between the factors were .672 and .782, and the correlation values between the factors and the scale total score were positive values ranging between .821 and $.931(\mathrm{p}<.01)$. This finding was interpreted as significant relationship between the factors constituting the CLSS and factortotal scale scores. As a result of confirmatory factor analysis, the ratio of chisquare value $\left(\chi^{2}\right)$ to degree of freedom (df) $\left(\chi^{2} / \mathrm{sd} ; 967.884 / 396=2.44\right)$ is acceptable; CFI compliance value (.92) acceptable compliance; RMSEA compliance value (.06) acceptable compliance; RMR (.038) value was found to be at the ideal fit level and the construct validity was confirmed.

In order to obtain information about the criterion validity of CLSS, it can be said that the sub-dimensions of CLSS are significantly related to Transformational and Releasing Leadership Styles and this result can be seen as sufficient for criterion validity. "Open-mindedness and flexibility" sub-dimension reliability coefficient was calculated as 0.94, Critical Decision Making and Ac- 
tions" sub-dimension was 0.92, "Research and Communication" sub-dimension was 0.91 , Focus on development and decision-making was 0.88 . The overall reliability coefficient was calculated as 0.969 . The reliability coefficients of the scale were found to be high. Item-residual correlation coefficients were between 0.631-0.742; item-total correlation coefficients ranged from 0.658 to 0.775 . While the arithmetic mean of the upper $27 \%$ group is above 4 or 4 , the arithmetic mean of the lower $27 \%$ group is below 3 or 3 . The $t$ values of the items were found to be significant $(\mathrm{p}<.01)$ and the items were found to be distinctive.

As a result of the test-retest method, the correlation coefficients of the factors were between 0.701 and 0.884 ; The correlation between the total score and the sub-dimensions ranged from 0.78 to 0.913 . According to these results, it can be said that the reliability of the scale in terms of stability is high. Subdimensions and item distribution of Critical Leadership Style Scale (CLSS) are given below:

Open-mindedness and Flexibility: 1, 2, 3, 4, 5, 6, 7, 8, 9, 10, 11

Critical Decision Making and Actions: 12, 13, 14, 15, 16, 17, 18, 19, 20, 21

Research and Communication: 22, 23, 24, 25, 26

Focus on Development and Decision Making: 27, 28, 29, 30

\section{Kaynakça / Reference}

Akan, D., Yıldırım, İ., ve Yalçın, S. (2014). Okul müdürlerinin liderlik stili ölçeği. Elektronik Sosyal Bilimler Dergisi, 13(51), 392-415.

Bennis, W. (1990). Why leaders can't lead: The Unconscious conspiracy continues. San Francisco: Jossey-Bass

Bolman, L. G., ve Deal, T. E. (2017). Reframing organizations: Artistry, choice, and leadership ( $6^{\text {th }}$ ed.). Hoboken, NJ: Jossey-Bass..

Brown, T. A. (2015). Confirmatory factor analysis for applied research, (2nd ed.). New York: The Guilford Press.

Büyüköztürk, Ş. (2014). Veri analizi el kitabı. Ankara: Pegem Akademi.

Büyüköztürk, Ş., Çakmak, E. K., Akgün, Ö. E., Karadeniz, Ş., ve Demirel, F. (2016). Bilimsel araştırma yöntemleri. Ankara: Pegem Akademi.

Day, D. V., Fleenor, J. W., Atwater, L. E., Sturm, R. E., ve McKee, R. A. (2014). Advances in leader and leadership development: A review of 25 years of research and theory. The Leadership Quarterly, 25(1), 63-82. 
DuBois, M., Hanlon, J., Koch, J., Nyatuga, B., ve Kerr, N. (2015). Leadership styles of effective project managers: Techniques and traits to lead high performance teams. Journal of Economic Development, Management, IT, Finance, and Marketing, 7(1), 30.

Ennis, R. H. (1985). A logical basis for measuring critical thinking skills. Educational Leadership, 43(2), 44-48.

Goryunova, E., ve Jenkins, D. M. (2017). Global leadership education: Upping the game. Journal of Leadership Education, 16(4), 76-93.

Hackman, M. Z., ve Johnson, C. E. (2013). Leadership: A communication perspective. Illinois: Waveland Press.

Hernández-Mogollon, R., Cepeda-Carrión, G., Cegarra-Navarro, J. G., ve Leal-Millán, A. (2010). The role of cultural barriers in the relationship between open-mindedness and organizational innovation. Journal of Organizational Change Management, 23(4), 360-376.

Jenkins, D. (2012).Global critical leadership: Educating global leaders with critical leadership competencies. Journal of Leadership Studies, 6(2), 95101.

Jenkins, D. M., ve Cutchens, A. B. (2011). Leading Critically: A Grounded Theory of Applied Critical Thinking in Leadership Studies. Journal of Leadership Education, 10(2), 1-21.

Katz, D. ve Kahn, R. L. (1977). Örgütlerin toplumsal psikolojisi (H. Can ve Y. Bayar, Çev.). Ankara: TODAİ Yayınları: 167.

Kotter, J.P. (1995). Leading change: Why transformation efforts fail. Harvard Business Review, 73(2), 59-67.

Llopis, G. (2015). 4 Constructive Ways Leaders Can Handle Criticism. Forbes. https://www.forbes.com/sites/glennllopis/2015/08/11/4-constructiveways-leaders-can-handle-criticism/\#76d98dde5615 adresinden 3 Mart 2018 tarihinde erişilmiştir.

Özdamar, K. (2016). Ölçek ve test geliştirme yapısal eşitlik modellemesi. Eskişehir: Nisan Kitapevi Yayınları.

Presseisen, B. Z. (1985). Thinking skills throughout the curriculum: A conceptual design. http://files.eric.ed.gov/fulltext/ED376133.pdf adresinden 13.12.2017, tarihinde erişilmiştir.

Saylık, N.( 2015). Okul müdürlerinin eleştirel liderlik yeterliliklerinin öğretmen görüşlerine göre incelenmesi, Yüksek lisans tezi, Yüzüncü Yıl Üniversitesi. Van. 
Seçer, İ. (2015) Psikolojik test geliştirme ve uyarlama süreci, Ankara: Anı Yayınc1lik.

Singh, N., ve Krishnan, V. R. (2007). Transformational leadership in India: Developing and validating a new scale using grounded theory approach. International Journal of Cross Cultural Management, 7(2), 219-236.

Sönmez, V. ve Alacapınar, F. G. (2016) Sosyal bilimlerde ölçme aracı hazırlama. Ankara: Anı Yayınları.

Vecchio, R. P. (2007). Leadership: Understanding the dynamics of power and influence in organizations. Indiana: University of Notre Dame Press.

Woods, P. (2012). Critical events in teaching ve learning. Oxon: Routledge.

Yukl, G. (2010). Leadership in organizations. Upper saddle river, NJ: Prentice Hall.

\section{$E k .1$}

Açıklama: Ölçek 30 maddeden ve 4 alt boyuttan oluşmaktadır. Ölçekte ters puanlanan madde bulunmamaktadır. Ölçekteki tüm maddeler toplanarak toplam puan elde edildiği gibi elde edilen toplam puan madde sayısında bölünerek aritmetik ortalamada elde edilmektedir. Alt boyutlar içinde aynı özellikler geçerlidir.

Açık fikirlilik ve Esneklik: 1, 2, 3, 4, 5, 6, 7, 8, 9, 10, 11

Eleştirel Karar Alma ve Eylemler: 12, 13, 14, 15, 16, 17, 18, 19, 20, 21

Araştırmacılık ve İletişim: 22, 23, 24, 25, 26

Gelişime Odaklanma ve Karar verme: 27, 28, 29, 30 


\begin{tabular}{|c|c|c|c|c|c|c|}
\hline \multicolumn{2}{|c|}{$\begin{array}{l}\text { ELEŞTİREL LIDERLIK STILİ ÖLÇEĞİ } \\
\text { Okul müdürüm; }\end{array}$} & \multirow{2}{*}{ 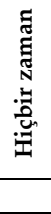 } & \multirow{2}{*}{ 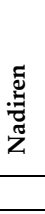 } & \multirow{2}{*}{ 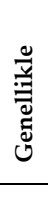 } & \multirow{2}{*}{ 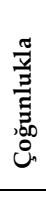 } & \multirow{2}{*}{ 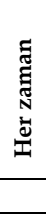 } \\
\hline 1. & Planladıklarını mutlaka hayata geçirir. & & & & & \\
\hline 2. & Harekete geçmeden önce tüm bilgileri edinmeye özen gösterir. & & & & & \\
\hline 3. & Her konuda alternatifler sunma eğilimindedir. & & & & & \\
\hline 4. & Problemleri açık ve net bir şekilde ifade eder. & & & & & \\
\hline 5. & Bir konudaki bilgi, beceri ve tecrübesini başka konular içinde kullanabilir. & & & & & \\
\hline 6. & Bir doğrunun her durumda ve her zaman doğru olamayacağını ifade eder. & & & & & \\
\hline 7. & Karar almadan ve harekete geçmeden önce varsayımları değerlendirir. & & & & & \\
\hline 8. & Değişime gitmeden önce mümkün olan tüm yolları keşfetmek ister. & & & & & \\
\hline 9. & $\begin{array}{l}\text { Değişime giderken örgütün yapısını ve süreçlerini anlamak için çaba göste- } \\
\text { rir. }\end{array}$ & & & & & \\
\hline 10. & Eylemlerinde kurumun misyon ve değerlerine bağlı kalır. & & & & & \\
\hline 11. & Alınan kararların konuya veya duruma uygunluğuyla ilgili sorular sorar. & & & & & \\
\hline 12. & Görev dağılımı yaparken çalışanların hazırbulunuşluklarını hesaba katar. & & & & & \\
\hline 13. & Çalışanların işi gerçekleştirme adına hangi seviyede olduklarını takip eder. & & & & & \\
\hline 14. & Çalışanların mesleki gelişimi için çaba harcar. & & & & & \\
\hline 15. & Bir iş çalşşanın yapabileceğinden daha zor ise bunu dikkate alır. & & & & & \\
\hline 16. & $\begin{array}{l}\text { Farklı seslerin ve farklılıkların okulun ortak amacına katkı sağlayacağını } \\
\text { ifade eder. }\end{array}$ & & & & & \\
\hline 17. & Çalışanların fikirlerini dinler ve farklı tavsiyelere açık kapı bırakır. & & & & & \\
\hline 18. & Doğru olduğunu düşündüğü davranışta inatçı değildir. & & & & & \\
\hline 19. & Her durumda karşısındakiyle empati kurmaya çalışır. & & & & & \\
\hline 20. & Eleştirileri olumlu karşılar. & & & & & \\
\hline 21. & Tek bir doğru yol olduğu konusunda ısrarcı değildir. & & & & & \\
\hline 22. & Problemi anlamak ve çözmek adına doğru sorular sorar. & & & & & \\
\hline 23. & Dinlerken anlamaya çaba gösterir. & & & & & \\
\hline 24. & Etkili ve sabırlı bir dinleyicidir. & & & & & \\
\hline 25. & Başkalarının kendi ile ilgili görüşlerine saygı gösterir. & & & & & \\
\hline 26. & Sorunları çözerken farklı bakış açıları sunar. & & & & & \\
\hline 27. & Çözüme ulaşmadan önce tüm varsayımları göz önünde bulundurur. & & & & & \\
\hline 28. & Mümkün olabildiğince olaylara farklı açılardan bakar. & & & & & \\
\hline 29. & Çalışanların düşünme becerilerini geliştirmeleri için çaba gösterir. & & & & & \\
\hline 30. & $\begin{array}{l}\text { Çalışanların düşünme becerilerini geliştirmek adına yönlendirici sorular } \\
\text { sorar. }\end{array}$ & & & & & \\
\hline
\end{tabular}

\section{Kaynakça Bilgisi / Citation Information}

Aygün, C. ve Özgenel, M. (2019). Eleştirel liderlik stili ölçeği: Geçerlik ve güvenirlik çalışması. OPUS-Uluslararası Toplum Araştırmaları Dergisi, 13(19), 1806-1835. DOI: 10.26466/opus.552489. 